\title{
THINKING WITH BALIBAR
}




\section{THINKING WITH BALIBAR}

A LEXICON OF CONCEPTUAL PRACTICE

ANN LAURA STOLER, STATHIS GOURGOURIS,

AND JACQUES LEZRA, EDITORS

Fordham University Press New York 2020 


\section{Copyright (C) 2020 Fordham University Press}

All rights reserved. No part of this publication may be reproduced, stored in a retrieval system, or transmitted in any form or by any means-electronic, mechanical, photocopy, recording, or any other-except for brief quotations in printed reviews, without the prior permission of the publisher.

Fordham University Press has no responsibility for the persistence or accuracy of URLs for external or third-party Internet websites referred to in this publication and does not guarantee that any content on such websites is, or will remain, accurate or appropriate.

Fordham University Press also publishes its books in a variety of electronic formats. Some content that appears in print may not be available in electronic books.

Visit us online at www.fordhampress.com.

Library of Congress Control Number: 2020904889

Printed in the United States of America

22212054321

First edition 